\title{
A new species of Parapsilorhynchus Hora, 1921 (Teleostei, Cyprinidae) from Mahanadi River basin of Odisha, India
}

\author{
B. K. BALIARSINGH AND LAISHRAM KOSYGIN* \\ ICAR-Central Institute of Freshwater Aquaculture, Bhubaneswar, Odisha - 751 002, India \\ "Zoological Survey of India, 27 J. L. Nehru Road, Kolkata - 700 016, West Bengal, India \\ e-mail:-bikram794u@yahoo.com
}

\begin{abstract}
A new cyprinid fish, Parapsilorhynchus swaini sp. nov., is described based on specimens collected from a stream near Harisankar, Mahanadi River basin of Odisha, India. It differs from other species of the genus in having following combination of characters: elongated and slender body (depth at dorsal fin origin 16.9-18.7\% SL); narrow and slender head (width 60.0-68.7\% HL, height at occiput 40.0-50.0\% HL); narrow inter orbital space (46.6-50.0\% HL); 33-34 lateral line scales; 3 simple pectoral fin rays, poorly developed callous pad behind lower lip which is not delimited posteriorly, pectoral fin longer than head length, presence of tubercles on snout and a black bar on the anal fin. With the description of this new species, distributional range of the genus Parapsilorhynchus is extended further north in the Eastern Ghats to the Mahanadi River drainage of Odisha.
\end{abstract}

Keywords: Cyprinidae, Mahanadi River basin, New species, Odisha, Parapsilorhynchus swaini

\section{Introduction}

The members of the genus Parapsilorhynchus Hora, 1921 (family Cyprinidae) are small-sized rheophilic fishes, which are distributed in hill streams of the Western and Eastern Ghats and the Satpura mountain ranges of India. Currently, the genus consists of five valid species viz., Parapsilorhynchus tentaculatus (Annandale, 1919), P. discophorus Hora, 1921; P. prateri Hora \& Misra, 1938; P. elongatus Singh, 1994 and P. odishaensis Baliarsingh, Kosygin \& Swain, 2017. They are characterised by having two blunt rostral barbels on the snout, 2 to 3 simple pectoral fin rays, upper lip concealed by a fringed rostral cap, which is covered with numerous papillae, prominent lower lip with a rudimentary disc or callous pad behind it, gill openings extending to the ventral surface and cyprinid type swim bladder. A recent ichthyological survey of the Mahanadi River basin in Odisha yielded five specimens of an undescribed species of Parapsilorhynchus. These specimens are herein described as Parapsilorhynchus swaini sp. nov.

\section{Materials and methods}

Measurements were made on the left side of the specimens with digital calipers to the nearest $0.1 \mathrm{~mm}$ following Jayaram (1999). Fin rays and numbers of scales were counted under a stereozoom microscope. Morphometric data are expressed in percentages of standard length (SL) or head length (HL) or caudal peduncle length. Fin rays counts of dorsal, pectoral, pelvic and anal fins include simple and branched rays. The type specimens were deposited in the Zoological Survey of India (ZSI), Kolkata.

\section{Results}

Taxonomy

Parapsilorhynchus swaini sp. nov. Baliarsingh \& Kosygin

Common name: Mahanadhi minnow

Holotype: ZSI FF5057, 42 mm SL (Fig. 1, Table 1. 2), caught off a stream near Harisankar, Mahanadi River basin in Odisha, India, $20^{\circ} 51^{\prime} 18.08^{\prime \prime} \mathrm{N} ; 82^{\circ} 51^{\prime} 37.75^{\prime \prime} \mathrm{E}$, Coll. B. K. Baliarsingh, 17 August, 2013.

Paratypes: ZSI FF 5058, 32-42 mm SL, 4 specimens, same data as holotype.

Diagnosis

Parapsilorhynchus swaini sp. nov. can be distinguished from other species of the genus by the following combination of characters: elongated and slender body (depth at dorsal fin origin 16.9-18.7\% SL); narrow and slender head (width $60.0-68.7 \% \mathrm{HL}$, height at occiput $40.0-50.0 \% \mathrm{HL}$ ); narrow inter orbital space (46.6-50.0\% HL); 33-34 lateral line scales; 3 simple pectoral fin rays, poorly developed callous pad behind lower lip which is not delimited posteriorly, pectoral fin 


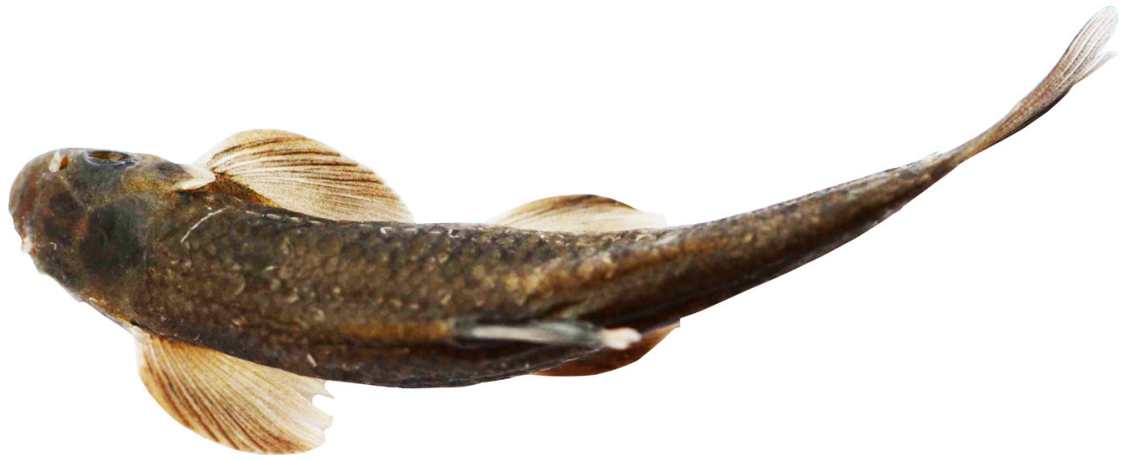

(a)

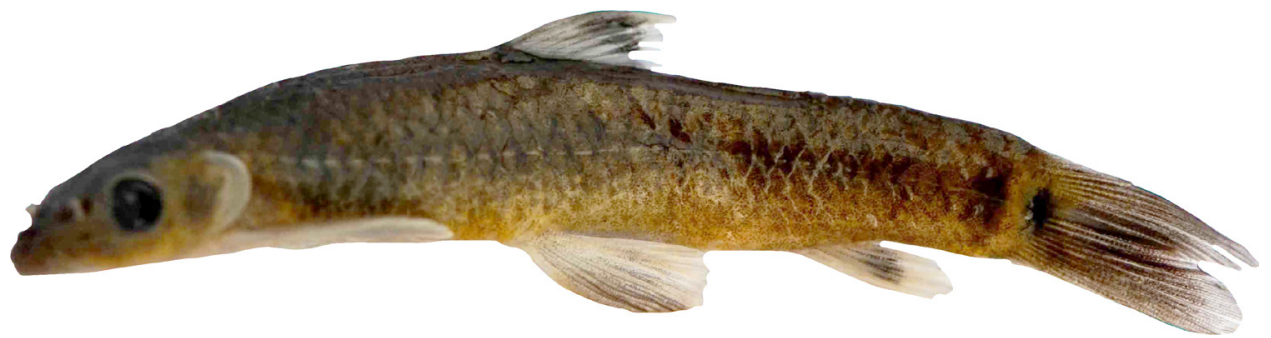

(b)

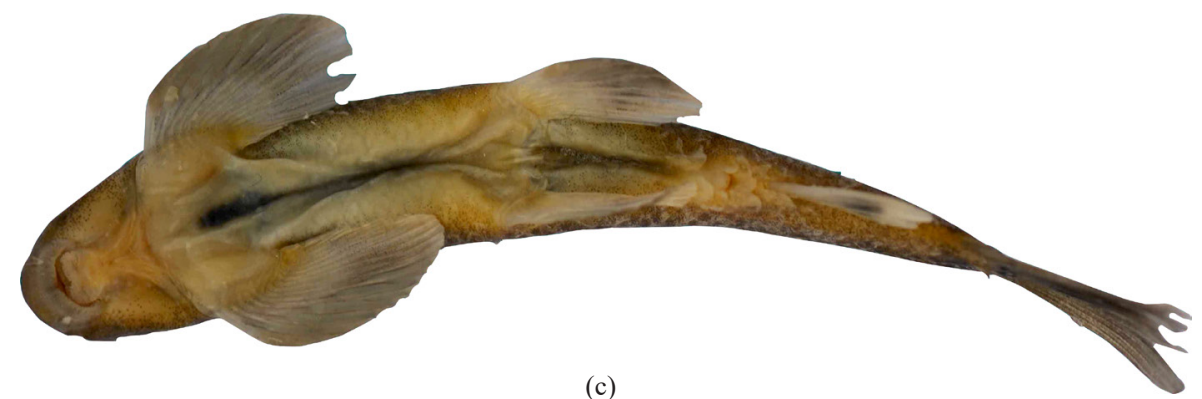

Fig. 1. Parapsilorhynchus swaini sp. nov., ZSI FF5057, holotype, $42.0 \mathrm{~mm}$ SL; (a) Dorsal, (b) lateral and (c) ventral views

longer than head length, presence of tubercles on snout and a black bar on the anal fin.

\section{Description}

Morphometric data of holotype and 4 paratypes are listed in Table 1 and 2. Body elongate, slender (Fig. 1), greatest depth at dorsal fin origin, ventral surface flattened. Head depressed with a prominent snout. Snout slightly rounded with a few poorly developed horny tubercles. Mouth small, inferior, crescent-shaped. Upper lip concealed by a prominent rostral fold, which is fringed and papillated. A groove present around the corners of the mouth, which is continuous anteriorly round the outer margin of the rostral fold. Lower lip bilobed, finely papillated, with a poorly developed callous pad behind it, which is not delimited posteriorly (Fig. 2). Eyes large, visible from ventral surface, its diameter smaller than inter orbital space. One rostral pair of barbels, shorter than eye diameter.

Dorsal fin with ii, 6 (1), ii, 6, i (3), or ii, 7(1) rays, inserted slightly in advance of pelvic fin, its origin almost equidistant between snout tip and caudal fin base. Pectoral fin with iii, 10, i (4) or iii, 11, i (1) rays, longer than head, not reaching pelvic fin origin. Base of the pectoral fin forms adhesive pads ventrally, with a few anterior branched rays and simple rays (Fig. 3). Pelvic fin with i, 5, i (5) ray, shorter than pectoral, not reaching anal opening. Anal fin base short, with i, 5 (5) rays, not reaching base of caudal fin. Lateral line complete with 33 or 34 scales. Scales in lateral transverse row above lateral line 4 or $4 \frac{1}{2}$ and below lateral line from pelvic fin origin $3 \frac{1}{2}$ or 4 . Predorsal scales 18-22, scales arranged irregularly. Chest and belly scaled. Caudal fin forked with i, 17, i (4) or i,18, i (1) principal rays. 
Table 1. Morphometric data of Parapsilorhynchus swaini sp. nov.

\begin{tabular}{|c|c|c|c|c|}
\hline \multirow{2}{*}{ Morphometric parameters } & \multirow{2}{*}{$\begin{array}{l}\text { Holotype } \\
\text { (ZSI FF 5057) }\end{array}$} & \multicolumn{2}{|r|}{ Paratypes } & \multirow{2}{*}{ Mean \pm SD } \\
\hline & & Min. & Max. & \\
\hline Standard length (mm) & 42 & 32 & 42 & $36.7 \pm 4.17$ \\
\hline \multicolumn{5}{|l|}{$\%$ Standard length } \\
\hline Head length & 22.8 & 22.5 & 23.5 & $22.9 \pm 0.48$ \\
\hline Body depth & 18.3 & 16.9 & 18.7 & $17.7 \pm 0.76$ \\
\hline Caudal peduncle length & 14.2 & 12.5 & 14.7 & $13.8 \pm 0.82$ \\
\hline Caudal peduncle height & 11.9 & 10.2 & 12.5 & $11.5 \pm 0.65$ \\
\hline Predorsal length & 50 & 50 & 53.5 & $51.3 \pm 1.43$ \\
\hline Prepectoral length & 14.2 & 13.7 & 18.7 & $16.2 \pm 2.17$ \\
\hline Prepelvic length & 50 & 50 & 53.1 & $51.3 \pm 1.34$ \\
\hline Preanal length & 73.8 & 73.8 & 81.2 & $77.7 \pm 3.11$ \\
\hline Preanus length & 71.4 & 70 & 75 & $71.8 \pm 1.97$ \\
\hline Dorsal fin height & 16.6 & 16.6 & 18.7 & $17.5 \pm 0.80$ \\
\hline Pectoral fin length & 24 & 24 & 26.5 & $25.2 \pm 0.89$ \\
\hline Pelvic fin length & 19 & 17.5 & 20.3 & $18.8 \pm 1.03$ \\
\hline Anal fin height & 19 & 14 & 19 & $16.2 \pm 2.05$ \\
\hline Caudal fin length & 25 & 22.5 & 25 & $23.6 \pm 0.89$ \\
\hline Distance from anus to caudal fin base & 25 & 21.2 & 25 & $23.4 \pm 1.64$ \\
\hline \multicolumn{5}{|l|}{ \% Head length } \\
\hline Head height at occiput & 41.6 & 40 & 50 & $43.9 \pm 3.80$ \\
\hline Head width & 67.7 & 60 & 68.7 & $65.1 \pm 3.69$ \\
\hline Eye diameter & 31.2 & 25 & 31.2 & $27.1 \pm 2.56$ \\
\hline Snout length & 38.5 & 33.3 & 40 & $37.4 \pm 2.48$ \\
\hline Inter orbital space & 46.8 & 46.6 & 50 & $48.7 \pm 1.80$ \\
\hline Mouth width & 26.0 & 26 & 31.2 & $28.5 \pm 2.50$ \\
\hline Rostral barbel length & 7.3 & 7.3 & 12.5 & $9.9 \pm 1.95$ \\
\hline \multicolumn{5}{|l|}{$\%$ Caudal peduncle length } \\
\hline Caudal peduncle height & 83.3 & 76 & 91 & $83.7 \pm 5.91$ \\
\hline
\end{tabular}

Min. $=$ Minimum, Max. $=$ Maximum; $S D=$ Standard deviation

Table 2. Meristic data of Parapsilorhynchus swaini sp. nov.

\begin{tabular}{lll}
\hline Counts & $\begin{array}{l}\text { Holotype } \\
\text { (ZSI FF 5057) }\end{array}$ & Paratypes \\
\hline Dorsal fin rays & ii,6,i & ii,6 or ii, $6, \mathrm{i}$ or ii, 7 \\
Pectoral fin rays & iii, $10, \mathrm{i}$ & iii, $10, \mathrm{i}$ or iii, $11, \mathrm{i}$ \\
Ventral fin rays & $\mathrm{i}, 5, \mathrm{i}$ & $\mathrm{i}, 7, \mathrm{i}$ \\
Anal fin rays & $\mathrm{i}, 5$ & $\mathrm{i}, 5$ \\
Caudal fin rays & $\mathrm{i}, 17, \mathrm{i}$ & $\mathrm{i}, 17, \mathrm{i}$ or $\mathrm{i}, 18, \mathrm{i}$ \\
Predorsal scales & 19 & $18-22$ \\
Lateral line scales & 34 & 33 or 34 \\
Lateral transverse scales & $4 / 1 / 4$ & 4 or $4 \frac{1}{2} / 1 / 3^{1 / 2}$ or 4 \\
\hline
\end{tabular}

\section{Colour}

Body dark grey with white ventral surface. A black horizontal bar or vertically elongated spot on the caudal peduncle. Dorsal and anal fins with a distinct black bar at the middle. All the fins dusky. Caudal fin with black longitudinal mark on median rays.

\section{Distribution}

Presently known from a stream near Harisankar, Mahanadi River basin in Odisha, India (Fig. 4).

\section{Etymology}

Named after Dr. S. K. Swain of ICAR-Central Institute of Freshwater Aquaculture (ICAR-CIFA), Bhubaneshwar for his encouragement and support in the present study.

\section{Discussion}

Parapsilorhynchus swaini sp. nov. is similar to $P$. elongatus in having an elongated body and 3 unbranched pectoral fin rays. However, the new species can be distinguished from $P$. elongatus in having lesser lateral line scales (33-34 vs 36), shorter predorsal length (50.0-53.5\% SL vs 56.2), pectoral fin longer ( $v s$ shorter) than head length, narrower interorbital space (46.6-50.0\% HL $v s$ 60.2-66.6) and presence ( $v s$ absence) of black bar 


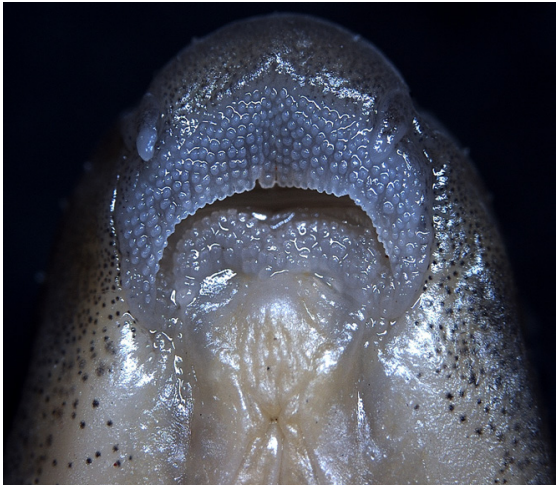

Fig. 2. Mouth of Parapsilorhynchus swaini sp. nov., holotype (ZSI FF 5057), $42 \mathrm{~mm} \mathrm{SL}$

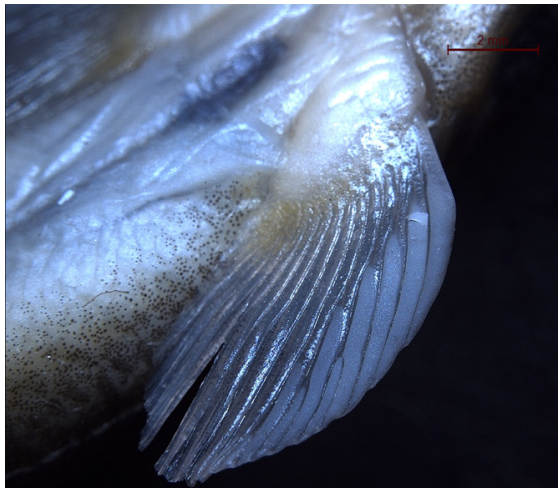

Fig. 3. Pectoral fin of Parapsilorhynchus swaini sp. nov showing adhesive pad

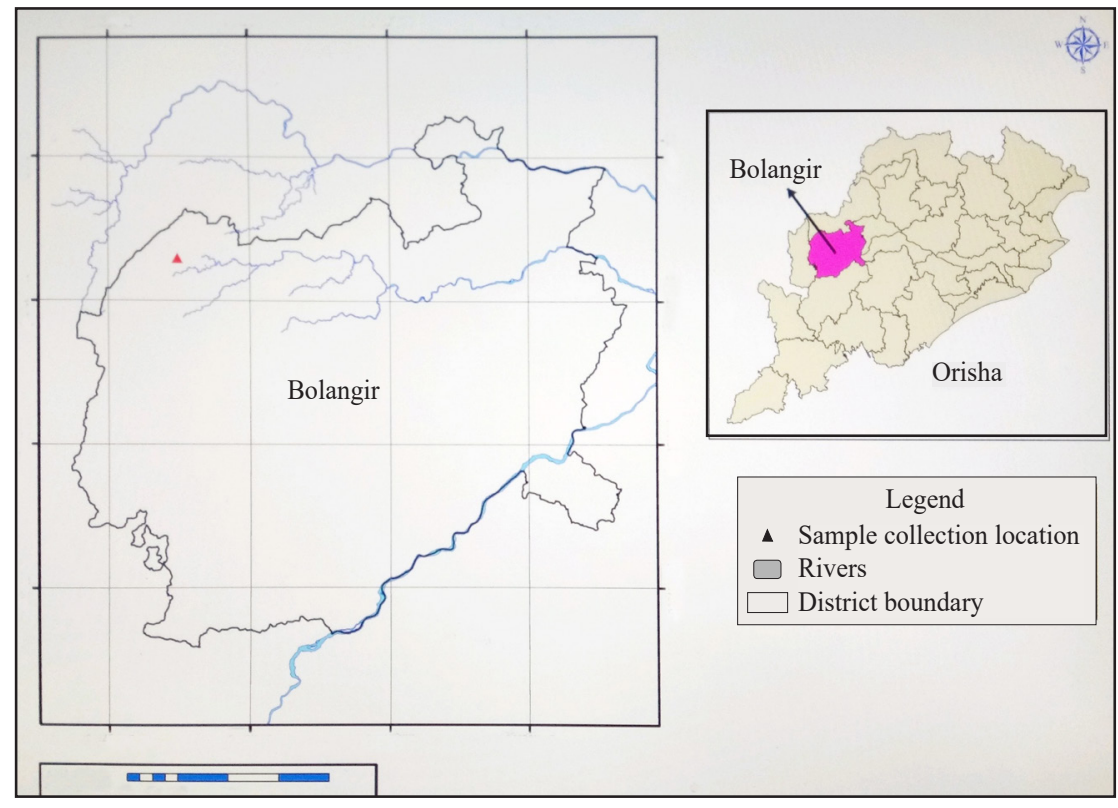

Fig. 4. Map showing type locality of Parapsilorhynchus swaini sp. nov

on the anal fin (Table 3). P. swaini sp. nov. differs from $P$. discophorus in having a poorly ( $v S$ prominently) developed callous pad behind the lower lip, which is not delimited posteriorly, a more slender body (depth at dorsal fin origin 16.9-17.6\% SL vs 18.3-24.2), more simple pectoral fin rays ( $3 v s 2)$, pectoral fin longer ( $v s$ shorter) than head and presence ( $v s$ absence) of a black bar on the anal fin.

P. swaini sp. nov. differs from $P$. tentaculatus in having lesser lateral line scales (33-34 vs 36-39), a more depressed head (height at occiput 40-50\% HL vs 61.1), eyes visible ( $v s$ not visible) from ventral side of head, presence ( $v s$ absence) of tubercles on the snout, presence of a vertical black bar ( $v s$ oval spot) on the caudal fin and presence ( $v s$ absence) of a black bar on the anal fin. The new species differs from $P$. prateri in having fewer lateral line scales (33-34 vs 43-47), a more depressed head (height at occiput 40-50\% HL vs 57.2-60.0), larger eyes (25.0-31.2\% HL vs 20.0-22.7) and poorly developed (vs well developed) callous pad behind the lower lip.

Recently, Baliarsingh et al. (2017) described Parapsilorhynchus odishaensis from the Mahendra Tanaya and Rushikulya Rivers in the southern part of Odisha. The new species is similar to P. odishaensis in having poorly developed callus pad, tubercles on the snout and 3 simple pectoral fin rays. However, P. swaini differs from $P$. odishaensis in having a more slender body (depth at dorsal fin origin 16.9-18.7\% SL vs 19.6-25.0), 
Table 3. Comparison of morphometric characters of different species of the genus Parapsilorhynchus

\begin{tabular}{|c|c|c|c|c|c|c|}
\hline Morphometric characters & $\begin{array}{l}\text { P. discophorus } \\
\text { (ZSI-WRCP/3817; } \\
\text { Hora, 1921) }\end{array}$ & $\begin{array}{l}\text { P. elongatus } \\
\text { (Singh, 1994) }\end{array}$ & $\begin{array}{l}\text { P. odishaensis } \\
\text { (Baliarsingh } \\
\text { et al., 2017) }\end{array}$ & $\begin{array}{l}\text { P. prateri } \\
\text { (Hora \& Misra, } \\
1938 \text { ) }\end{array}$ & $\begin{array}{l}\text { P. swaini sp. nov. } \\
\text { (ZSI FF5057 \& } \\
\text { FF5058) }\end{array}$ & $\begin{array}{l}\text { P. tentaculatus } \\
\text { (Type ZSI F 9695/1) }\end{array}$ \\
\hline \multicolumn{7}{|l|}{$\%$ Standard length } \\
\hline Body depth & $18.3-24.2$ & 17.2 & $19.6-25.0$ & $17.0-18.7$ & $16.9-18.7$ & 22.2 \\
\hline Predorsal length & $49.1-54.7$ & 56.2 & $51.5-57.1$ & - & $50.0-53.5$ & 52.8 \\
\hline \multicolumn{7}{|l|}{$\%$ Head length } \\
\hline Head height at occiput & $40.9-49.1$ & - & $57.2-75.0$ & $57.2-60.0$ & $40.0-50$ & 61.1 \\
\hline Head width & $59.1-73.0$ & - & $71.4-94.1$ & $72.7-73.0$ & $60.0-68.7$ & 72.2 \\
\hline Eye diameter & $23.5-30.8$ & $22.2-30.3$ & $18.7-28.6$ & $22.0-22.7$ & $25.0-31.2$ & 27.9 \\
\hline Inter orbital space & 56.2 & $60.2-66.6$ & $53.3-64.3$ & $47.3-50.0$ & $46.6-50$ & 50.0 \\
\hline Mouth width & $32.6-40.0$ & - & $23.5-28.6$ & - & $26.0-31.2$ & - \\
\hline Lateral line scale & $33-35$ & 36 & $33-35$ & $43-47$ & $33-34$ & $36-39$ \\
\hline Pectoral fin rays & 2 & 3 & $3-4$ & - & 3 & 3 \\
\hline $\begin{array}{l}\text { Horny tubercles } \\
\text { on the snout }\end{array}$ & $\begin{array}{l}\text { Absent/poorly } \\
\text { developed }\end{array}$ & Absent & $\begin{array}{l}\text { Well } \\
\text { developed }\end{array}$ & Absent & $\begin{array}{l}\text { Poorly } \\
\text { developed }\end{array}$ & Absent \\
\hline $\begin{array}{l}\text { Visibility of eye from } \\
\text { ventral side of head }\end{array}$ & Visible & Visible & Visible & Visible & Visible & Not visible \\
\hline Pectoral fin length & $\begin{array}{l}\text { Shorter than head } \\
\text { length }\end{array}$ & $\begin{array}{l}\text { Shorter than head } \\
\text { length }\end{array}$ & $\begin{array}{l}\text { Equal or longer } \\
\text { than head length }\end{array}$ & $\begin{array}{l}\text { Equal to head } \\
\text { length }\end{array}$ & $\begin{array}{l}\text { Longer than } \\
\text { head length }\end{array}$ & Damaged \\
\hline Shape of lower lip & Rounded & Bilobed & Rounded & Rounded & Bilobed & Bilobed \\
\hline Callous pad & Well developed & Poorly developed & Poorly developed & Well developed & Poorly developed & Poorly developed \\
\hline Black bar on anal fin & Absent & Absent & Absent & Absent & Present & Absent \\
\hline
\end{tabular}

slender and narrower head (depth at occiput $40-50 \%$ HL vs 57.2-75.0; 60.0-68.7\% HL vs 71.4-94.1), smaller interorbital space $46.6-50.0 \%$ HL vs 53.3-64.3), poorly (vs prominently) developed tubercles on snout, presence ( $v s$ absence) of adhesive pads at the base and ventral surface of simple rays of pectoral fin, a bilobed ( vs rounded) lower lip and a distinct black bar on anal fin.

Yazdani and Singh (1991) pointed out that fishes of the genus Parapsilorhynchus possess peculiar combination of characters, which they share with other cyprinid subfamilies. However, based on the osteological studies they remarked that Parapsilorhynchus has its own distinctive characters not found in the related subfamilies. They also remarked that Parapsilorhynchus appears to have common origin with the related genus Psilorhynchus, which occurs in the Himalayan region as they have similarities in general morphology and habitats. Fishes of the genus Parapsilorhynchus were considered endemic in the Western Ghats and the Satpura mountain ranges of India (Singh, 1994) except $P$. tentaculatus which was also reported from Eastern Ghats in Andhra Pradesh (Rama Devi and Menon, 1995; Rema Devi and Indra, 2003). However, P. odishaensis, was described recently from the Eastern Ghats of India (Baliarsingh et al., 2017). With the description of this new species, distribution of the genus is further extended to north in the Eastern Ghats to the Mahanadi River drainage of Odisha.

\section{Comparative materials}

Parapsilorhynchus discophorus, 4 ex., 26.4-32.0 mm SL, ZSI-WRCP/3817; India: Vasishti River, Pophli, Ratnagiri District, Maharashtra. Additional data from Hora (1921) and Yazdani and Rao (1977).

Parapsilorhynchus odishaensis, holotype, $35.0 \mathrm{~mm} \mathrm{SL}$, ZSI FF 4625; India: Mahendra Tanaya River, Tiniamba Village, Rayagada District, Odisha. Additional data from Baliarsingh et al. (2017).

Parapsilorhynchus prateri, type, $36 \mathrm{~mm} \mathrm{SL}$, ZSI F 12498/1; India: Deolali, Maharashtra. Additional data from Hora and Misra (1938).

Parapsilorhynchus tentaculatus, type, 1ex., $36 \mathrm{~mm} \mathrm{SL}$, ZSI F 9695/1; India: small hill-streamlets at Khandalla, Poona District, Maharashtra. Additional data from Annandale (1919).

Parapsilorhynchus elongatus: Data from Singh (1994).

Key to species of Parapsilorhynchus

1. Lateral line scales less than 43 .......................................... 2

Lateral line scales 43-47 ....................................... P. prateri

2. Callous pad well developed ………………………............. 3

Callous pad poorly developed ................................................ 
3. Pectoral fin with 2 simple rays, its length shorter than HL; Lateral line scales 33-35 P. discophorus

Pectoral fin with 3 simple rays, its length longer than HL; Lateral line scales 36 P. elongatus

4. Lateral line scales 36-39; eyes not visible from ventral side of head P. tentaculatus

Lateral line scales 33-35; eyes visible from ventral side of head 5

5. Body depth $19.6-25 \%$ SL; Anal fin without black bar . P. odishaensis

Body depth 16.9-18.7\% SL; Anal fin with a black bar P. swaini sp. nov.

\section{Acknowledgements}

We are grateful to Dr. Kailash Chandra, Director, Zoological Survey of India, Kolkata for allowing us to examine type specimens of Parapsilorhynchus. We are thankful to Avinash Jena for the help during the collection of fishes and to Dr. Shrikant Jadhav of Western Regional Centre, ZSI, Pune for providing related literature.

\section{References}

Annandale, N. 1919. The fauna of certain small streams in the Bombay Presidency. V. Notes on freshwater fish mostly from the Satara and Poona districts. Rec. Indian Mus., 16(1): 125-138.

Baliarsingh, B. K., Kosygin, L. and Swain, S. K. 2017. Parapsilorhynchus odishaensis, a new cyprinid fish
(Teleostei: Cyprinidae) from Odisha, India. Rec. Zool. Surv. India, 117(1): 22-25.

Hora, S. L. 1921. Notes on fishes in the Indian Museum. I. On a new genus of fish closely resembling Psilorhynchus, McClelland. Rec. Indian Mus., 22(1): 13-17.

Hora, S. L. and Misra, K. S. 1938. Fish of Deolali. Part III. J. Bombay Nat. Hist. Soc., 40(1): 20-38, Pls. 1-3.

Jayaram, K. C. 1999. The freshwater fishes of the Indian region. Narendra Publishing House, Delhi, 551 pp.

Rema Devi, K. and Indra, T. J. 2003. An updated checklist of Ichthyofauna of Eastern Ghats. Zoos' Print J., 18(4): 1067-1070.

Rema Devi, K. and Menon, A. G. K. 1995. First record of Parapsilorhynchus tentaculatus (Pisces: Cyprinidae) from the Eastern Ghats, India. Ichthyol. Expl. Freshw., 6(3): 279-282.

Singh, D. F. 1994. Parapsilorhynchus elongatus, a new cyprinid fish from the Western Ghats, India. J. Bombay Nat. Hist. Soc., 91(2): 282-285.

Yazdani, G. M. and Babu Rao, M. 1977. On the validity and redescription of Parapsilorhynchus discophorus Hora with a key to the species of the genus. Biovigyanam, 3: 247-249.

Yazdani, G. M. and Singh, D. F. 1991. Taxonomic status and phylogenetic relationship of little known hill stream fish of the genus Parapsilorhynchus (Cypriniformes). Rec. Zool. Surv. India, 89(1-4): 43-52. 